\title{
James Joyce's Ulysses: The Search for Value
} Aouda Aljohani*

\begin{abstract}
Two chapters, "Scylla and Charybdis" and "Penelope," in James Joyce's Ulysses are crucial to an understanding of the novel as a whole. "Scylla and Charybdis" stands midway in the novel, the ninth of eighteen chapters, and is designed to serve as a kind of exegesis of the writer's methods and intentions. An analysis of that chapter helps to explain the meaning of the controversial final chapter, "Penelope," and to clarify its thematic and stylistic relation to the text as a whole. Ulysses is the story of a quest, actually of many quests that all coalesce into a single goal: the search for value in a modern world that is somehow diminished and constructed in comparison with the Homeric world where mortals strode the universe in company with gods and goddesses. How, in this dwarfed setting, can men and women redefine heroism in secular humanistic terms relevant to twentieth-century life? Almost by definition a quest narrative culminates in the attainment of the goal or in the potential for its attainment; Joyce's Ulysses affirms this possibility in "Penelope."
\end{abstract}

Keywords: James Joyce; Ulysses; Scylla; Charybdis; Penelope

\footnotetext{
* Corresponding author: Aouda Aljohani; Assistant Professor, Institute for Research and Consulting Studies, Taibah University, Saudi Arabia; e-mail: drjohani99@hotmail.com.
} 
Joyce has provided us with a way to approach "Penelope" by explaining the aesthetic, the modus operandi that informs the total work, in "Scylla and Charybdis," though in relying on "Scylla" for a perspective it is essential to make certain discriminations. While the aesthetic theory that Stephen annunciates in "Scylla and Charybdis" is in certain fundamental ways Joyce's own, Stephen at this point cannot be conflated with Joyce. Stephen, as we see him in the library, could never have written Ulysses, and so the chapter is as much about what is lacking in the would-be artist as it is about the genesis of art. In this most self-reflexive of chapters, thematic threads from the preceding chapters are gathered for us into a more coherent pattern. Stephen's problems are highlighted, as are the pitfalls lying in wait for him; we realize more clearly that some experience or relationship must occur if he is to become an artist. Above all, we are introduced to a new character who, like the Ghost in Hamlet, will be the architect and controlling force of all that happens. This character is Joyce, the completed artist, who makes his authorial presence consistently felt "Scylla and Charybdis" to a degree not apparent in the previous eight chapters. Here, with his punning, his word play that mimics or parodies the movements and speeches of the characters, and his stage directions, he is very much in the foreground as he will continue to be (at times outrageously so in the tour de force of "Oxen" and "Circe") in varying degrees until "Penelope." In "Scylla and Charybdis," then, we have a theory of art presented by a character who is not yet an artist, written by an artist who in many ways can be identified with Stephen, and who uses, through Stephen, the supreme artist, Shakespeare, to explain how the book Ulysses could ever have been written at all. In other words, there is a lack here that must be filled for the book we are now reading to have been created. "Penelope" is the celebration of the force that can rescue "seabedabbled" Stephen from the place in which we see him in "Scylla and Charybdis."

In the library scene, Stephen is struggling with a lot of psychic pressure. Here he is, a young man known to have artistic aspirations addressing a group of literary men, but he is extremely aware that so far he has accomplished nothing. He had left Dublin to escape the stifling influences of Irish life, Catholicism, and his family, but six months later he has had to return, summoned to his mother's deathbed. The flight to Paris has produced nothing of artistic significance; he has returned not covered with achievement but as a 
"lapwing," a bird known for scavenging about dung heaps. What a contrast to the lyrical flight that he had envisaged in Portrait:

Fabulous artificer. The hawklike man. You flew. Where to? Newhaven-Dieppe, steerage passenger. Paris and back. Lapwing Icarus. Pater, ait. Seabedabbled, fallen, weltering Lapwing you are." Lapwing be (Ulysses, IX, 946-7).

Stephen feels poor and isolated; he owes money to one of the men present and cannot repay it. Bitterly he remembers he squandered it on a prostitute. Even his appearance gives him pain the almost-mockery of his Latin Quarter hat, the affectation of his stick, his too-tight boots:

Stephanos, my crown. My sword. His boots are spoiling my feet. Buy a pair. Holes in my socks. Handkerchief too. (Ulysses, IX, 946-7).

But these signs of failure are slight compared to the torments of guilt that he feels abouthis mother's death and his refusal to pray for her. The refusal was part of his credo, his determination not to serve a Church that he regards as oppressive. But now that refusal and the vision of his supplicating mother haunt him:

Mother's deathbed. Candle. The sheeted mirror. Who brought me into this world lies there, bronzelidded, under few cheap flowers. Liliata rutilantium (Ulysses, IX, 221-3).

Grief is always difficult to handle, but it is agonizing when combined with guilt and anger. For Stephen does also feel rage towards his mother, as his chain of ideas shows. The lines quoted above follow immediately a description of Ann Hathaway, adulteress, burying her family. The association comes not just through death but also through the theme of betrayal, for his mother has not reserved the privileged position of son and lover for him. Stephen, like Hamlet, is both preoccupied with -- and repulsed by thoughts of his mother as a sexual being. When he thinks of her, as he does obsessively through the day, the images peculiarly combine death and sexuality. On an unconscious level, was Stephen punishing his mother for the sexual life she had led with his father when he refused her dying wish? Does he see her sexual life that produced so many other children, so many rivals for his mother's love, as weakening and leading to death?

Bridebed, childbed, bed of death, ghost candled... He comes, pale vampire, through storm his eyes, his bat sails 
bloodying the sea, mouth to her mouth's kiss (Ulysses, III, 396-9).

There are suggestions of incestuous longings; the mother "betrays" the son who wants to be preeminent with her by taking another man to bed. That man is a "usurper" on one level by taking the son's place in his mother's love; on another level, he is a usurper because his claims of paternity are not legitimate. Within the Hamlet configuration, Claudius tries to appropriate a fatherly relationship to Hamlet, just as he wrongfully appropriates a place in Hamlet's mother's bed. Similarly, Stephen wants to reject Simon's paternity because he feels that Simon fits in all too well with the paralyzing mores of the Dublin whose influence Stephen is determined to flee

He's Irish (Simon Dedalus), bold the seaman affirmed...All Irish. Irish, All too Stephen rejoined(Ulysses, XVI, 382-3).

In Stephen's mind, his mother, as quintessential female and therefore as Virgin, muse, and mistress, has betrayed him by mating with his father, the man whom he has rejected as alien to his nature:

Wombed in sin darkness. I was too, made not begotten.

By them, the man with my voice and my eyes...They clasped and sundered, did the coupler's will(Ulysses, III, 45-7).

Stephen longs to escape the flesh, to see himself begotten as the apostolic successor to Shakespeare, his true spiritual father. He would appropriate paternity for himself, become his own father to his own sonhood, consubstantial and autogenic. Stephen's theories of androgyny, the self-created artist God are in many ways disguised versions of his fear of sexuality, a fear that Mulligan, ever watchful for means to deflate Stephen, touches on in his ribald parody, "Everyman His Own Wife" (Ulysses, IX, 1171).

Stephen is thus alone, alienated from his country, his Church, and his human family, paralyzed by guilt and surrounded by people whom he fears will either betray him or fail to take him seriously. With these pressures what can he do but rely on his formidable intellect, "unsheathe [his] dagger definitions," and do his Shakespeare shtick, which Mulligan has already mockingly alluded to as their day commenced on the Tower (Ulysses, IX, 84)? Stephen wants to make 
himself felt, for it is galling that Mulligan and Haines, the usurpers, have admittance to literary gatherings to which he is uninvited. He needs to dazzle here: "Composition of place. Ignatius Loyola, make haste to help me" (Ulysses, IX, 153).

Stephen weaves a complex and sometimes contorted theory regarding Shakespeare and the biographical forces that shaped his work. He pictures the young Shakespeare as having been seduced by Ann, the olderwoman. Shewas the aggressor; and, since hers was the conquest, Shakespeare never felt truly self-confident as a man:

He was chosen, it seems to me. If others have their will Ann hath a way (notice the pun here; Joyce outdoes himself in this chapter). By cock, she was to blame (Ulysses, IX, 256-7).

Ann, the "boldfaced Stratford wench," then went on to betray Shakespeare and the marriage now by sleeping with none other than his brothers, the wicked Uncles Richard and Edmund, on whom he revenged himself in Richard III and King Lear, just as he rewrote his life and obtained revenge against Ann by writing Hamlet (Ulysses, IX, 973-4). Some of Stephen's biographical details -- such as the incestuous uncles, the London strumpets, the identity of the loved one of the Sonnets, the role of Marina -- would be hard to substantiate. Stephen makes mistakes, sometimes intentionally; Robert Greene was referring to lust, not Shakespeare, with the phrase, "A deathsman of the soul" (Ulysses, IX, 130). At times, Stephen seems only to want to impress and knowingly distorts materials, putting "poison" or misinformation into the ears of his listeners: "And in the porches of their ears I pour..." (Ulysses, IX, 465 and Hamlet, I, 5, 63). The dating of the love affair between Ann and Shakespeare is incorrect, but Stephen will not reveal his willful misrepresentation: "Don't tell them he (Shakespeare) was nine years old when it [the supposedly significant firedrake] was quenched (Ulysses, IX, 936).

But discrepancies such as these, while making us wary and underscoring Joyce's ironic detachment from Stephen, are really details in comparison with the broad thrust of Stephen's theory. Stephen, like Joyce, is sincere about the relation of the artist, Shakespeare, to his work; art has its genesis in the life experience of the artist that is somehow objectified by his genius to achieve universal significance. The character Hamlet is particularly attractive to Stephen, for he sees him as an 
iconographic representation of himself and the pressures he feels -alienated, paralyzed by grief and guilt, betrayed and bested by usurpers. In Stephen's view, Shakespeare is not Hamlet, but the Ghost who uses the play to rewrite his life and to create his revenge:

Is it possible that that player Shakespeare, a ghost by absence, and in the vesture of buried Denmark, a ghost by death, speaking his own words to his own son's name (had Hamlet Shakespeare lived he would have been prince Hamlet's twin), is it possible, I want to know, or probable that he did not draw or foresee the logical conclusion of those premises: you are the dispossessed son: I am the murdered father: your mother is the guilty queen, Ann Shakespeare, born Hathaway (Ulysses, IX, 174-80)?

Stephen and Joyce here too -- is saying that art springs from the life of the artist, his direct, painful, and bruising contact with the world. For an artist, there are no mistakes in life: "His errors are volitional and are portals of discovery (Ulysses, IX, 228-9). Stephen, speaking for Joyce as well, is defining his aesthetic in opposition to the prevailing Platonism of his audience, the rarified atmosphere of the aesthetes, and the withdrawal from real life of the Revivalists who would linger perpetually in the romance of the Celtic twilight. Stephen feels antagonism toward his audience for artistic reasons and because he feels their indifference to him. They also have power, while he is feeling impotent:

Where is your brother? Apothecaries' hall. My whetstone. Him, then Cranly, Mulligan: now these. Speech But act. Act speech. They mock to try you. Act. Be acted on (Ulysses, IX, 977-9).

As a chapter that twice replicates a play in its type- set, "Scylla" becomes a reenactment of Hamlet in which Stephen casts his listeners collectively as Claudius, himself as young prince, and Joyce, his future father, as the Ghost. The terms father and son refer respectively to the Ghost and Hamlet, to the mature and the young Shakespeare, to Joyce and to Stephen; in all these cases father and son are one and the same being. As in the Sabellian view of the Trinity, the Son, the Father, and the Holy Ghost are not distinct entities, they are consubstantial. The Father is His Own Son, and Joyce, the 
ghost of the unquiet father, looks down from the future seeing himself in his own sonhood. There is a growth of the soul from immaturity (where we now see Stephen in all his self-doubt and paradoxical hubris) to fatherhood and maturity, the stage at which the soul can turn around upon itself and express a vision of itself in art. To evoke the Trinity in an aesthetic discussion shows the exalted, quasi-mystical role that Stephen and Joyce see for the artist, harkening back without ironic connotations to Stephen's view of the artist-priest as forging "the uncreated con- science of my race (Joyce, 1966, 253).

But Stephen here is far from having achieved this stature. His is putting himself in the line of apostolic succession to Shakespeare, an appealing thought that enables him to reject Simon Dedalus' fatherhood and to claim the supreme artist as his true progenitor, as he had earlier with Dedalus. Biological paternity can be dismissed as a fiction. Who is the father of any son that any son should love him or he any son (Ulysses, IX, 844-5)? Stephen is a lost young man in search of a father, in search of sexual experience that will inspire rather than degrade, and in search of an identity with which he can feel comfortable. Right now his poseur, Mulligan's "lovely mummer," and though he rejects the abstractions of Platonism and the lurking effeminacy of the Aesthetes, he still is in many ways drawn by temperament to their styles (Ulysses, I, 97). By inclination, he would step back from raw life and try to turn charged emotion into something less threatening. His life is turned inward, and he is too prone to turn a pretty phrase rather than to confront his problems. He feels real grief, for example, but his psychic energy is bent almost narcissistically towards the phrasing of it; in the opening chapter he twice describes his dead mother in the same words, almost as though he were still searching for le mot juste, though he is thinking to himself and not speaking (Ulysses, I, 102-5; 270-73). Such narcissism, "Scylla and Charybdis" suggests, can lead to other forms of onanistic sterility. Since art is pictured as the act of creation, it implies heterosexual love, as that is the only kind of love that calls forth creation. The chapter isrife with allusions to homosexuality, "the love that dare not speak its name," and with reference to Wilde and Swinburne, whose sexual proclivities were notorious (Ulysses, IX, 659). Ironically, it is the false friend, Mulligan, the Judas, who warns Stephen about homosexual love as he signals Bloom's departure from the library (Ulysses, XVI, 98):

...The sheeny! Buck Mulligan cried. He jumped up 
and snatched the card...What's his name? Ikey Moses? Bloom Ikey Moses? Bloom ...? He knows you. He knows your old fellow. O I fear me, he is Greeker than the Greeks. His pale Galilean eyes were upon her mesial groove (Ulysses, IX, 601-7; 614-15).

The reference to Greeks is Buck's pass at homosexuality; "the old fellow" refers both to Stephen's father and his penis. "His pale Galilean eyes" is one of many phrases pointing to an identification of Bloom with Christ (an identification Stephen himself will make in "Eumaeus"),(Ulysses, XVI, 1091-3) though Mulligan, the anti-Semite, is hardly offering it in tribute. Swinburne's "Hymn to Proserpine" contains the line, "Thou has conquered, o pale Galilean" (Gifford and Seidman, 1974, 184). Swinburne and "pale" both connote a kind of limp-wristedness, The irony, of course, is that Buck, with his invidious back-biting and nay-saying, is the real danger to Stephen; Mulligan's negativity is sterile, and he is the one appearing to flirt with homosexuality. As a false priest whose humor is only a disguise for his malignancy and even envy of Stephen, Buck Mulligan's is the influence that Stephen must avoid. Bloom's sphere is what he must find since Bloom represents the "Agenbuyer," or "Redeemer" in Middle English, for Stephen's paralyzing "Agenbite of inwit," his remorse of conscience (Ulysses, X, 582). Bloom, with a "touch of the artist" about him, lives like Stephen a lot in his imagination His Agendath Netai is the Eastern oasis of his sensual dreams, but he is also in touch with the external world in a vital, compassionate, and empathetic way that Stephen is not. Above all, he has a deep bond with a woman, unlike Stephen who is basically fearful of woman in the flesh: "Eve. Naked wheatbellied sin. A snake coils her, fang in his kiss" (Ulysses, IX, 541).

Significantly, in the last scene of "Scylla and Charybdis" it is Bloom who passes between... and thus separates Stephen and Buck as he exits. In a flash of some sort of psychic recognition, Stephen senses on an unconscious level what Bloom can offer him, a channel to generosity of spirit and sexuality from which he is now cut off:

A man passed out between them, bowing, greeting...Good day again, Buck Mulligan said. The portico. Here I watched the birds for augury. Aengus of the birds. They go, they come. Last night I flew. Easily flew. Men wondered. Street of harlots after. A cream fruit melon he held to me. In. You will see 
(Ulysses, IX, 1203-8).

With this thought, Stephen prefigures his rendezvous with Bloom and summons from dimmest memory his enigmatic dream:

The man led me, spoke. I was not afraid. The melon he had held against my face. Smiled: cream fruit smell (Ulysses, III, 366-8).

It is not until the "Oxenof the Sun" episode that Bloom and Stephen are really together in the same place at the same time in any kind of meaningful way, and not until their shared mirror image in "Circe" followed by their quiet companionship in "Eumaeus" and their cocoa communion in "Ithaca" that there is some kind of crystallization of their relation- ship, and even then disappointingly brief on a literal level. However, the function of "Scylla and Charybdis" is to give insight into why Stephen needs Bloom in order to avoid the perils of the library circle: a surrender to an uninnovative literary career (let's say a derivative poet or playwright on the order of a third-rate Synge or Yeats) or a flight from sexual fears and inadequacies into sterile homosexuality. "Scylla and Charybdis" ties together suggestions, correspondences, and allusions from the previous chapters and defines the direction in which Joyce is pointing us: the epiphanic moment on a metaphorical level that awaits Stephen and Bloom in "Ithaca," and finally us, as still questing readers, in "Penelope." Before "Scylla and Charybdis," we have had suggestions that Bloom and Stephen must somehow come together, for their ability to fill one another's lacks is apparent. Bloom, as a Jew, feels isolated from Catholic Ireland; socially he is the outsider. He also feels cut off from the home and woman he loves because he knows that the usurper, Blazes Boylan, will be making love to his wife this very afternoon and possibly supplanting him in her affections. Longing thoughts of Molly, images of passion and of a cuckold's pain, haunt his day, just as Stephen's guilt haunts his. Bloom grieves for his dead son and for his father's suicide; Stephen longs for a father figure, for a sense of identity, for recognition, and for love. Bloom and Stephen, like the Hamlet who figures in both their thoughts, are obsessed by the themes of paternity and usurpation; both are anticlerical and dismaled by the "Irishness" of the Irish, their loud but ineffectual nationalism, their history of betraying each other and theirleaders, and their cringing submission to their temporal and spiritual rulers. Both substitute fantasy for reality in their sexual lives, though Bloom does so 
with a kind of creative gusto, while Stephen seems to try to abstract himselffrom even that physical act or to feel ashamed.

Joyce goes further to presage their eventual coming together by showing us how Bloom and Stephen's thoughts interpenetrate and by fusing their identities with symbols that overlap or refer to one another. Stephen and Bloom are both associated with Christ. Bloom is the "pard" of "Scylla and Charybdis," an animal that denotes Christ (Gifford, 1974, 207). Like Christ, Bloom is compassionate and also like Christ, he is rejected (Bloom is disdained by many of his fellow Dubliners) After Bloom defends his Jewishness against the rabid nationalism of the Gaelic barflies ("Cyclops") by saying, "Christ was a Jew," his exit is punctuated by a seismic eruption like that which occurred after the Lord's crucifixion. In "Eumaeus" Bloom confides this painful experience to Stephen; he is both pained and proud. His remark is a wonderful example of his resiliency, a quality Stephen must assimilate, and of the humor that transforms the novel from satire, cruel and biting, to comedy, mirthful and reflective (in Meredith's terms):

Your God was a Jew. Because mostly they appeared to imagine he came from Carrick-on-Shannon or some whereabouts in the county Sligo (Ulysses, XVI, 164042).

The theme of rejection and betrayal ties in with Stephen (the artist who would be free in repressive Dublin) and with, about whom Stephen and Bloom both think. The threemasted schooner Rosevean (three crosses onCalvary) is Stephen's emblem, and Bloom'semblem floats by:

Elijah, skiff, lightcrumpled throwaway, sailed eastward by flanks of ships and trawlers, amid an archipelago of corks, beyond new Wapping street Past Benson's ferry, and by the threemasted schooner Rosevean from Bridgwater with bricks (Ulysses, X, 1096-10).

The prophet Elijah's relevance to Bloom as person is that he is to be the reconciler of sons to fathers and fathers to sons; he is relevant to Stephen-Christas the herald of the Second Coming. This manipulation of symbols is characteristic of the way Joyce draws our attention to the connection between Stephen and Bloom so that we will see their metaphorical coming together as the end of their quest. Stephen is Telemachus mytho-poetic searching for his father, the wandering 
Ulysses-Bloom (although the actual extent of Bloom's wanderlust is hilariously rendered in Eumaeus). Bloom, as a Dubliner, searches for a son; and as Ulysses, strives to regain his home and wife. Stephen, as Icarus, must find a spiritual father who will help him achieve his artistic potential and become, in terms of "Scylla and Charybdis," his own father, emerging as the Creator-God who will make the word flesh, or text, in the process by which Shakespeare transformed his life experience into art. The crucial role that the encounter with Bloom will play in helping Stephen go from possible to actual is suggested by the three faces, Bloom's, Stephen's and Shakespeare's, appearing fused in the mirror at the brothel ("Circe").

In "Eumaeus" and "Ithaca" what happens between Stephen and Bloom on a literal level is disappointing. We, as readers who have voyaged this far, would like to hear words of affection, the kind a commitment to further meetings, and more than of "o you saw that matutinal cloud too" dialogue that establishes the many connections as well as dissimilarities between them. But that would simply not be consistent with the way the novel has worked; throughout we have been asked to convey stature and meaning on ordinary people and events. Bloom has a heroic capacity to be compassionate and to love; his quickness to sympathize is in contrast to the hostility and selfish mean-spiritedness that has surrounded him in his encounters during the day. At the same time, we see him in all his foibles and least heroic stances -- in the outhouse and masturbating on the beach. What is at work here is an example of Stephen's term "hypostasis," literally the doctrine that explains that Christ was both God and man (Ulysses, VII, 783). With Bloom and with the novel as a whole, we are called upon to see the divine, or heroic, as it is consubstantial with the mortal, or ordinary. We must therefore understand the interchange and communion between Stephen and Bloom in "Eumaeus" and "Ithaca" on a metaphorical level, even if we are literally only seeing them as they urinate side by side. As "Bloom Stoom" and "Stephen Blephen" they express their mutual recognition just as the initials D. B. in Murphy's name suggest that we see a union of D (Dedalus) and B (Bloom), particularly when Shakespeare is tossed into the equation: "Cicero, Podmore, Napoleon, Mr. Goodbody. Shakespeares were as common as Murphies" (Ulysses, XVI, 363-4). Now really, how common a name could Shakespeare ever have been! But this is Joyce, and he will not gratify us with long, solemn, finally tying it altogether statements. 
Instead, he will evoke communion with a few stunning images. We see Bloom and Stephen as two small human figures gazing up together at the vastness of the night sky," the heaventree of stars hung with human night blue fruit (Ulysses, XVII, 1039). Simultaneously they perceive a signfrom the heavens implying Stephen's movement toward Bloom:

A star precipitated with great apparent velocity across the firmament from Vega in the lyre above Zenith beyond the star group of the Trees of Bernice toward the zodiacal sign of Leo (Ulysses, XVII, 1210-13).

The image also points to the fulfillment of Stephen's artistic potential (he will have the poetic power that Orpheus had with his lyre) and to the intensity of love that the later artist, Joyce, feels for Nora, as well as the role of love in releasing artistic potential and power in men (Gifford, 1974, 480). The celestial imagery signifies that the union of Stephen and Bloom was destined to be, that it will have profound significance for Stephen in his transformation into an artist, and that it will offer Bloom a new kind of paternity since he has, on the metaphorical level, helped to create the artist:

The appearance of a star (1st magnitude) of exceeding brilliancy dominating by night and day (a new luminous sun generated by collision and amalgamation in incandescence of two nonlurninous exsuns) about the period of the birth of William Shakespeare over delta in the recumbent never setting constellation of Cassiopeia and of a star (2nd magnitude) of similar origin but of lesser brilliancy which had appeared and disappeared from the constellation of the Coronal Septentrionalis about the period of the birth of Leopold Bloom and of other stars of (presumably) similar origin which had (effectively or presumably) appeared in and disappeared from the constellation of Andromeda about the period of the birth of Stephen Dedalus, and in and from the constellation of Auriga some years after the birth and death of Rudolph Bloom, junior... (Ulysses, XVII, 118-30).

While it is Stephen and Bloom who are together, the influence of Molly is paramount to the meaning of all that transpires. "Scylla and Charybdis," in its discussion of the Trinity, and of the artist's 
position in it, has made the principle of triangulating images and ideas part of our experience of reading the novel. Here Molly, as muse and generative Virgin Mary, the Queen of Heaven, is very much present metaphorically as the third part of the scene, joining the Father and the Son. Bloom's and Stephen's climactic moment of recognition comes about under Molly's sign, the sign of the lamp shedding light down upon them:

...What visible luminous sin through...fellow faces (Ulysses, XVII, 1171-1184).

We're seeing a revelation: the metaphoric union of the artist-intellectual with twentieth-century everyman, materialistic, vulgar, half-educated, but with vitality which Stephen has lacked (Schwarz, 1987). It is Bloom's passion for Molly that distinguishes him above every other characteristic, and so we must turn to Molly if we are to understand the power of this transforming force. Molly is asked, by the metaphoricity of the text and by her position at the end of the quest narrative, to support a tremendous burden of meaning. Joyce further pumps up our expectations regarding Molly in letters to his friends that have become so often quoted and so familiar that our response to Penelope has become almost preconditioned. We are looking for one of the Goddesses whom Bloom has inspected at the Museum, and this Goddess, with her notoriously obscene reputation, will definitely come with holes. In letters to his friend, Frank Budgen, and to his indefatigable and frequently chagrined and perplexed benefactress, Harriet Weaver, Joyce points to what has become the classical response to the Penelope chapter:

Your description of it [regarding "Penelope to Weaverwho had described it as prehuman] also coincides with my intention...if the epithet post human were added. I have rejected the usual interpretation of her as a human apparition...that aspect being neither represented by Calypso, Nausica and Circe, to say nothing of pseudo Homeric figures. In conception and technique I tried to depict the earth which is prehuman and presumably posthuman (Ellman).

and to Budgen:

["Penelope"] begins and ends with the female word yes. It turns like a huge earth ballslowlysurelyand evenly 
round and round spinning, its four cardinal points being the female breasts, arse, womb and cunt expressed by the words because, bottom (in all sense bottom button, bottom of the class, bottom of the sea, bottom of his heart), woman, yes. Though probably more obscene than any preceding episode it seems to me to be perfectly sane full amoral fertilisable untrustworthy engaging shrewd limited prudent indifferent Weib (Scott, 1984, 158).

Both these passages point to the qualities of "Penelope" that are most appealing in giving the book the sense of a search successfully concluded. As the evocations of nature and passion grow in lyrical intensity, the chapter does give a sense of peace, affirmation, and timelessness. Molly seems above and beyond history; while Bloom is very much a man of his period and Stephen is imprisoned in the nightmare of history, Ireland's and his own. With her affirmation, Molly seems to be a reconciler of opposites. Her femaleness is the fluid medium that dissolves difference, and the antagonisms that have permeated he text seem trivial in comparison to her timelessness. William York Tindall's description of Molly beautifully sums up the way "Penelope" does give Ulysses a kind of swelling grandeur, of monumentality; and of resolution:

As fundamental and symbolic as a cat, she appears as "GeaTellus" or "earth-earth," fulfilled, recumbent, big with seed. By its redundance this name expresses her meaning. Larger than individual Mrs. Bloom and far older, she is the Great Mother of the Ancients. Her monologue which begins with "Yes," and uses "yes" as its refrain suitably ends with "yes." From its immediate reference to Bloom, this final word is raised by the chapter that precedes it and by the book that it ends to a general affirmation. The last two pages of the book are a hymn to God and Nature. The center of natural life, she praises it.

Bloom's equanimity resolves his private tensions. By her existence and her position at the end Mrs. Bloom resolves the tensions of the book...By her irrationality she reconciles all rational conflicts. Stephen and Bloom, conflicting opposites, become one in her. As she thinks of 
them, their differences fall away to leave them united in a common being. She is the great agent of reconciliation and its symbol (Tindall, 1950, pp. 36-7).

This is true and certainly encapsulates the impression that most readers have of the book as they remember it. The enduring appeal of this interpretation sterns not only from the fact that it is right on in many ways, but also because it gives a surface facility to the novel that is reassuring after the constant obfuscations we have met along the way. But there is another aspect to this chapter that deals with the literal Molly and which yields a somewhat different perspective, a less easily summarizable viewof what isgoing on.

As "Scylla and Charybdis" makes clear, Joyce believes that art springs directly from the life experience of the artist and that it is wrested from the tensions and conflicts of that life experience, especially those from the sexual arena. It is certainly no secret that Ulysses is one of the most autobiographical of books on many levels, and that the story takes place on that day in 1904 that Joyce privileges as the date on which Nora Barnacle made a man of him by initiating him into sexual life that was not simply a commercial transaction with a prostitute. Ulysses is Joyce's epithalamion, a tribute to the artistically empowering nature of Nora's love and to her uniqueness as a personality:

Through Nora Barnacle, he found the madonna and muse who could both inspire his art and satisfy his most arcane sexual desires. Nora was the imaginary motherjwife whose extravagant sexuality finally released the inhibitions, both artistic and sexual, that once had stifled her shy, but willing sonjlover, Jimmy Joyce. In a passionate invocation, Joyce wrote to her: "Guide me, my saint, my angel. Lead me forward. Everything that is noble and exalted and deep and true and moving in what I write comes, I believe, from you (Henke and Unkeless, 1982, 8).

Much of the specificity about the characterization of Molly comes from this desire to pay homage to Nora; it is not too bad a thing to be portrayed as the muse that liberated an artist's gifts. In "Penelope" Joyce attempts to step inside the mind of Molly/Nora, or more exactly, re-create that mind, and for this reason he uses a new 
technique in the chapter. It is the only one in the book that is pure internal monologue with no intrusions or stage directions from the narrator. It is as though this stream of words, unarrested by even the guidance of punctuation, is meant, in its freedom and fluidity, to suggest the freedom of mind and spirit that characterize both Molly and Nora. "Specificity" does seem like an odd term to use in describing a character who is often seen as one huge abstraction, but Molly is actually presented as a very specific person, and the originality of her discourse is one aspect of this individuality. Molly's rush of words reminds us of Nora's volubility, as does her sharp tongue. Molly's unpunctuated style comes from Nora's letters:

well what have you to say to Jim now after all our little squabbles he could not live without me for a month...all the people here were talking about him for running after me...

Ellmann's Letters and Maddox's biography are helpful in showing exactly how closely Joyce did model Molly on Nora. The word choice, the unpunctuated style, the skepticism, and, above all, the wit are pure Nora. Evidently her remarks were treasured within the Joyce circle; Ellmann particularly admired the succinct report she gave Joyce after looking at an apartment to let: "The place wasn't fit to wash a rat in” (Ellman, 1966, 302). But Nora did not like the book, and made no secret of her aversion to it. She read only small sections of Ulysses, refused to go any further, and told Frank Budgen that what she had read she found obscene. She must also have been disturbed to see so much of her private correspondence, her obscene letters, in print:

For Nora some passages were worse than obscene, they were shameful revealing things she cannot have believed Joyce wanted to reveal...Nora aversion to the book could also have sprung from recognition. Too many of the lines were her own. She may even have written some of them (Maddox, 1988, 204).

Joyce himself refused to identify Molly as Nora and Nora pooh-poohed the resemblance by saying that Molly was "much fatter." Nevertheless, "Penelope" is a kind of public tribute to her role as muse, although the novel, and "Penelope" in particular, has very private 
meanings as well. "Penelope" is a rewriting of significant aspects of their domestic and sexual history, with the tensions and ambivalences exposed. "Penelope" reanimates issues from "Scylla" and offers a reexamination of some of the trans-sexual and masochistic fantasies of "Circe,"ostensibly from Molly's (or in these terms, Nora's) point of view. But every word of this was arranged by a masculine mind; the material came from Joyce's psyche and from his memory (what Joyce defined as "imagination"). We are seeing "woman" as an abstraction and as an individual from a male perspective, and an extremely idiosyncratic one at that:

...as we know from Joyce's letters to Nora, his creation of ambiguous Molly had little to do with an ethic of scrupulous responsibility toward the truth of "humanity." Rather, if there is a principled adherence toward anysort of truth in "Penelope" it is to the subjective truth of his own nature (Schechner, 1974, 203).

In "Penelope" Molly is not just a placid Earth Mother, she is an angry, unsure, sarcastic, and frustrated Mrs. Leopold Bloom. And she has a lot of reasons to be angry. Molly has not had normal intercourse for ten years. The loss of their son, Rudy, has incapacitated Bloom with guilt; he sees his inability to produce a living male heir in terms of a loss of virility. In the meantime, however, she and her husband have continued to lead a cozy married life, her mate seemingly content to sleep head-to-tail and to kiss her bottom, her "melons," as sort of evening benediction. Occasionally there have been more passionate encounters; but, still and all, she feels she is aging because she is not living fully as a woman:

I can't help it if I'm young still can I its a wonder I'm not an old shrivelled hag before my time living with him so cold never embracing me except when hes asleep the wrong end of me not knowing I suppose who he has (Ulysses, XVIII, 1388-1401).

Above all, her husband's passivity and infantilism have made her doubt her womanly attractions. For all her narcissism (she, like Gerty, talks about herself as though she were the heroine of a soft porn novel), she has doubts about herself sexually and her main concern is to please her lover:"I wonder is I was too heavy sitting on his knee" (Ulysses, XVIII, 342). One of the most poignant parts of her 
reverie is her fear that Boylan's peaches and pears warm-up basket is actually a put-off, "thinking he was trying to make a fool of me." Here we see the actual Molly, not the sexpot that has been gossiped about by the strutting Dublin males or fantasized about by Bloom who sees her as the irresistible hot-blooded Spanish temp- tress. Molly is not even very experienced, and she is better at amorous reverie that at amorous activity. Hugh Kenner, after analyzing the Ithaca list of purported lovers, nembers them, before Boylan, "between 0 and 1." (Kenner, 1974). Blazes is more important to her in terms of validating her attractiveness as a woman than for the stud services he can provide. Kenner speculates that Molly actually tries to put Blazes off by exhausting him. How else, Kenner asks, did the heavy walnut sideboard that Bloom bumps into ever get moved in the first place? Molly couldn't have done it alone, and their present maid is tottering. It is a wonderful theory, and we can only know for certain that it did not work, since Molly reports that Blazes' sexual vigor must be explained by a large consumption of oysters or even a whole sheep! (Ulysses, XVIII, $145 ; 151)$.

Molly's view of men is not all that flattering to the male ego; the "usual idiots of men" are anatomically ugly ("no wonder they hide it with a cabbage leaf"), are sexually inexpert and selfish ("they want to do everything too quick and take all the pleasure out of it"), and they are infantile ("they're so weak and puling when they're sick") (Ulysses, XVII, 368; 544; 315-23). Molly sees women as better able to bear pain, more adult, and better able to run the world, given a chance: "They [men] haven't half the character a woman has" (Ulysses, XVIII, 837). If she has doubts about men in general, she does notflatter Boylan either. He seems coarse and unrefined to her; even her view of him as a lover is highly ambivalent. She certainly was not charmed by his bedroom manners, and the phrase"determined vicious look" hardly sounds romantic: "like a stallion driving it up into you with that determined vicious look in his eye" (Ulysses, XVIII, 152-3). She also was not pleased by his casually slapping her bottom as he left as though she were a horse or an ass. He is vulgar and without real feeling for a woman, an "ignoramus that doesn't know poetry

from a cabbage" (Ulysses, XVIII, 1370). Boylan indeed stacks up negatively against Bloom of whom she seems more and more fond as she compares him with other men. Molly is far from the loose woman we have anticipated. She does want to "have a bit of fun," but she has not been promiscuous (Ulysses, XVIII, 8-9). She 
has waited a long time for her first affair; the list of suitors is in Bloom's mind and in the prurient talk of the macho men of Dublin. The absence of Gardiner in Bloom's speculations should invalidate the list, for he seems to be the only one, other than Mulveu, her first love, for whom she felt any real affection, and his place may be special because she regrets his needless death.

What is Molly really like then? She is not well educated (though she is oddly proud of Bloom's hodgepodge of learning), she is a bit vulgar, and she has a sharp and sardonic kind of wit as she laughs at the world around her: "and his [John Henry Menton's -- one of her alleged suitors] boiled eyes of all the big stupoes I ever met and thats called a solicitor." But she also has a kindness that is like Bloom's; she feels sorry for the firemen on trains who are away from horne all night; she pities the horses who are ripped open at the bullfights; she hates the carnage of war and thinks of the soldiers as "poor devils" (Ulysses, XVIII, 686). She is often criticized for her jealously toward Milly, but what mother has not felt a twinge of envy as she sees herself as she once was in the person of her daughter? It is a very difficult period, particularly when her husband does not reassure her sexually. There is a kind of flirtation between Milly and her father as the young girl tests out her powers in the archetypal family romance (it is interesting to remember Joyce's own jealously with regard to his son Giorgio):

I noticed he was always talking to her lately at the table explaining things in the paper and she pretending to under stand sly of course that comes from his side of the house..and helping her into her coat..I suppose he thinks I'm finished out and laid on the shelf (Ulysses, XVIII, 1019-1022).

But for all her scolding and irritation, we feel that Molly loves her daughter (she pridesherself on the care she gave Milly during teething and mumps and her daughter's continuing need of her), and we see her suffering from Rudy's death with a pain that haunts her. Above every other trait, we see in Molly a deep and abiding commitmentto her Poldy, even if she phrases a lot of her feelings about him in ways that sound patronizing:

"of course hed never find another woman like me to put up with him the way I do" (Ulysses, XVIII, 232-3). She is very protective of her position with him, although she disclaims any interest in his sexual comings and goings. Her jealousy and competitiveness are 
obvious, whether she is scorning the fired servant as a "slut," relishing her triumph over Bloom's former love, Josie Breen, or just watching Bloom s little flirtations. She notices the Clifford note just as Bloom noticed the Boylan billet doux. This element of almost mutual titillation is one of the intriguing aspects of "Penelope": there is a kind of sexual collusion between them. There is also more than a bit of the voyeur about Bloom; here we see Molly s awareness of it just as we had seen in the phantasmagorical pantomime of "Circe," where Bloom masochistically pro- motes, watches, and encourages Boylan $\mathrm{s}$ performance. In "Penelope" Molly thinks that Bloom has sent Milly away so that the coast will be clear for Boylan:

only had do a thing like that all the same on account of me and Boylan that's why he did it I'm certain the way he plots and plans everythingout (Ulysses, XVIII, 1008-9).

Bloom's behavior with Stephen suggests a similar intent with connotations of incest as well, since Stephen is in some ways to fill the role of the lost son. "Penelope" suggestion that Bloom may have manipulated the Boylan tryst is but one instance of the way Joyce wrote some of the sexual dynamics of his own marriage into the text. Joyce was aroused bythe thought of his wife with other men, as much as he was dismayed by the thought that his wife could be unfaithful. In psychological terms, he used jealously to provoke his artistic urges, and he needed art to assuage the fears that his jealousiesprovoked; clearly Joyce's tex in "Scylla and Charybdis" is as much about James Joyce as it is about Stephen and Shakespeare:

The wish to exhibit his wife, Joyce was well aware, masked at the very least yearnings toward adultery...In pursuit of that vicarious thrill, Joyce in 1918 and 1919 hoped that Nora would be strong where he was weak...

Nora knew what Joyce wanted; she also knew that she was being used and resented it. As so often, she translated Joyce's own beautifully worded but veiled thoughts into plain words, with terrifying accuracy. One night, leaving a cafe with Frank Budgen, as Joyce lagged some way behind, Nora burst into tears. "Jim wants me to go with other men," she told Budgen, "so that he will have something to write about (Madox, p. 159). 
Interestingly, Joyce portrays Molly's attitude toward Bloom as exasperated but ultimately forgiving. She ruefully says, "Of course hes not natural like the rest of the world" and gives us a picture of why she can say, "there isn't in all creation another man with the habits he has" (Ulysses, XVIII, 268; 1198). The habits include sleeping with his feet toward her face, all curled up like a fetus, and questioning her about all the men she has ever known. He becomes aroused by the inquisition:"question and answer would you do this that and the other with the coalman yes with a bishop yes I would.”(Ulysses, XVIII, 89-90). She feels he is trying to make a "whore" out of her, and that he is obsessed by dirty words, fetishes (her drawers)and by an association of excrement with sexual arousal (Ulysses, XVIII, 98; 267). But though these practices seem perverse, there is a way in which they also satisfy an aspect of Molly's psychological make-up. While Bloom has been almost emasculated by grief and guilt over Rudy's death (his feeling of being sexually inadequate because he is sonless), Molly too has been devastated as a woman. She has asserted her maternal role by becoming psychologically Bloom's mother. She has the kind of fond, superior, but watchful attitude that mothers have for appealing but wayward little boys. Molly satisfies Bloom's dependency needs, and Bloom, for all the surface problems, also satisfies her need to feel powerful and in control. Here we glimpse the psychological acuity of "Circe;" the surreal is a way to approach the reality of Molly's and Bloom's relationship as we see it in "Penelope," while "Penelope" sheds more light on the sexual drama of the earlier chapter. In Molly's musings we see a way of living with Bloom that redefines traditional sexual roles; the masculine side of her nature, her desire to control, will have expression, and the feminine side of Bloom's nature, his compassion and love of domesticity, will also find release:

The unfettered musings that reveal her to us as readers also permit her to discover in herself, and to rationalize, repressed tendencies. Among these is the need for the sort of relationship she could have with Bloom, a duel between de Sade and Sacher-Masoch...

Much of "Penelope" then is remarkably close to the most intimate aspects of Joyce's life with Nora. Nora's exuberant sexuality liberated a shy, unsure, young man. He could not get over how she took the initiative and performed the deft act just as he had Molly 
perform the handkerchief trick with Mulvey (read Mulvagh, Nora's Galway swain) in "Penelope." Her sexuality represented for Joyce more than just sex; it was part of the rebelliousness of her spirit a defiance of the way "nice" Irish girls were supposed to be offering their bodies to their husbands from duty and seeing themselves as vessels for procreation. Nora was almost masculine in her sexual assertiveness and this was a source of wonder to her mate who had had very little sexual experience other than with prostitutes:

Joyce was delighted but slightly over whelmed. One night, naked, she straddled him like a horse, urging, "Fuck up, love! Fuck up,-love!" Her behavior fulfilled all his dreams of domination by a fierce woman, and that Nora could release such fervor only three weeks after initiation left him with a lasting sense of awe at the banked fires of female desire (Madox, p 57).

The Joyces' domestic life proceeded harmoniously until the birth of their son Giorgio, when Joyce became very jealous. Did the birth of their son not duplicate the experience Joyce had had of displacement earlier, when, as eldest child, his mother had had to turn her attention from him with the births of successive siblings? The theme of mother as betrayer has two parts: Mother betrays her child by having other children and thus robbing him of his preeminence (think of the usurping Shakespearebrothers in "Scylla"), and Mother betrays son by having sexual relations with Father who is the son's natural rival and who is, in Joyce's lexicon, an in- tegral part of the repressive patriarchal order of Dublin from which he must escape.

Joyce's jealousy and fear of betrayal were ignited when, on a visit to Ireland, he was told by his old friend Vincent Cosgrave that he, Cosgrave, had had relations with Nora. Joyce was horrified and lost confidence in himself and in Nora. He remembered that there was not a lot of blood on the sheets from their wedding night, though he had proudly writ- ten his brother Stanislaus about the deflowering (and that's odd in itself). This incident had such significance for Joyce that he wrote it into "Penelope," but this time it's from Molly's wry perspective:

and they always want to see a stain on the bed to know you're a virgin for them all that's troubling them they're such fools too you could be a widow or divorced 40 times over a daub of red ink would 
do... (Ulysses, XVIII, 1125-7).

Joyce's anguish was horrible and only subsided when his friend J. F. Bryne told him Cosgrave's story was a lie. Joyce did not forget, and Cosgrave appears as Lynch in Portrait, despised name in Ireland, the name of a magistrate so cruel that he betrayed his own son and hanged him. On the other hand, Bryne, the reconciler, lived at 7 Eccles Street, which will become the house of reconciliation in Ulysses. The parallels with the Shakespeare story in "Scylla" are striking. There Stephen had insisted that Shakespeare was taken by a more experienced woman, and is this not our impression of Howth as well, in terms of the woman manipulating the man? For Bloom, Howth is a paradisal memory; for Joyce, his "Howth" marks both a glorious initiation into a sexual relationship with Nora and a cause of anxiety. If she acted so boldly with him is itbecause she had practiced with others?

Tell me. When you were in that field... with that other (a "friend" of mine).. Did you place your hand on him as you did on me in the dark and did you say to him as you did to me, "What is it, dear?" (Ellmann, pp. 232-3).

In "Scylla" passion both ignited the creative gift and caused insecurity, since the artist was aware that the woman, not he, had been the aggressor. Love, in "Scylla," does not seem to be enough; the artist must also betortured by doubts and jealousies. The wound (the "tusk of the boar") is a necessary condition for the tensions from which art will arise as the artist struggles to re-write his life through his work and thus surmount those tensions (Ulysses, IX, 459-60).The interpenetration of art and life went even further in Joyce's life as Joyce demanded that Nora prove her love for him by becoming the woman of his most "Circean" fantasies. Nora could no longer just be herself; he coached her in writing erotic letters that would be aids to masturbation, just as Bloom's were to Molly in "Penelope." The letterswere to be proof of what she would do for him:"Write more and dirtier, darling" (Maddox, p. 105). Above all, the letters written by Nora, but ghostwritten by Joyce, tapped into the world of sadomasochistic fantasy that Joyce found most cathartic. If, he wrote, his obscenity offended her, she was to flog him as she had done in the past. This was Nora's cue to reply in an angry letter featuring lots of lashings and a domineering woman who would punish him as a mother woulda verybad boy. The references to smutty words in 
"Penelope" come from this aspect of their relationship as do the references to fetishism -- Bloom is "mad on the subject of drawers (Ulysses, 289). Joyce's letters were evidently very explicit and acted as guidelines toward what Nora was supposed to reply. It's all there in "Penelope," even the anal and cloacal obsessions that made Joyce prefer drawers with brown stains on them to those that were pure white (Maddox, p. 104). Their correspondence bound them in a way that is hard to understand if we do not remember how really frightened this Jesuit-trained young man was of sex. To unleash and reveal his innermost feelings to a woman and to have that woman participate in that psychological disrobing established a private world of commitment for which Joyce felt a gratitude verging on wonder. She was his "beautiful wildflower of the hedge,' as Molly was the "flower of the mountain" for Bloom (Schechner p. 281 and Ulysses, XVIII, 1576).

Nora represented for Joyce a woman whose spirit and sexuality fused the disparate strands of his own desire and reconciled his ambivalences. For him she uniquely combined in one persona the figures of mother, muse, whore and mistress. He wished, like the figures of the Trinity in "Scylla," to see himself absorbed into her:

take me into your soul of souls and then I will become indeed the poet of my race. I feel this, Nora, as I write it. My body soon will penetrate into yours, o that my soul could too! Othat I could nestle in your womb like a child born of your flesh and blood, slee in the warm secret gloom of your body (Schechner, pp. 247-8).

This fusion reaches its ultimate expression in "Penelope" where Joyce, the androgynous creator-God from "Scylla," explores, in a privileged subtext, his own marriage, and, from the female point of view, affirms a lasting commitment to himself as Stephen-Bloom. Joyce, speaking as a female, acknowledges the torturous twists of his masculine sexuality, but lyrically celebrates the enduring nature of the relationship, a belief that is essential to his survival as man and artist. To read the final chapter then as anything other than a paean to Molly or Nora as the embodiment of love and its redemptive and transfiguring powers is to disregard the import of "Scylla and Charybdis." This reading unifies the literal level of the chapter, in which we see a very human woman with very human thoughts and desires, with the mythic level in which we see a woman who is more than human, elemental 
and timeless. The meaning on both levels is the same and presents another aspect of "hypostasis" in which the Divine and the human are co-mingled. We are being asked to apprehend that love is a powerful force existing throughout time and present for all men. It is "the word known to all men," but we must choose to feel its power and be transfigured by it.

With love as the climacticaffirmation of "Penelope," we wonder if perhaps it was wise for Gabler to have reinserted the phrase, "Love, yes. Word known to all men," back into "Scylla and Charybdis," when it had been omitted by Joyce in earlier editions, possibly by error (as Bagler believes) or possibly by intention (as we do). The quest for meaning, for the "Word," has been the motif of the book. Stephen asks his mother for the word in the "Circe" scene; how does this make sense if he already knows it in the earlier library scene? Stephen's mother refuses to tell him then, almost as though she feels he is not yet ready to be receptive. He is still too angry and turned inwards. But the word, "love," with its connotations of reaching out to others through emotional empathy, sounds very much like what she had wished him to find at the end of Portrait:

She prays now, she says, that I may learn in my own life and away from home and friends what the heart is and what it feels (Portrait, p. 252).

Is it possible that Joyce never wished the word to be directly stated at all, but inferred as we are to infer so much else in the text? Could our discovery of the word be part of a pattern that he has established? In Martha Clifford's letter she says she does not like that "world," but she means to say "word." Martha, in fact, does not know the "world" or the word "love;" she has accepted the world of fantasy for her romantic life. Bloom's name is reported in the newspaper incorrectly with the "L" (that Martha inserted incorrectly) omitted. Should we be thinking about the letter itself and its significance in certain crucial words? It is, after all, the first letter of the word "love," as well as of "logos." Are we to remember also that Bloom is referred to repeatedly as the "apostle to the Gentiles," the Jew who brought the Word, or light, to them? The word, for Paul, of course, in First Corinthians is love. Without love even the gift of prophesy is hollow:

Though I speak with the tongues of men and of angels, and have not charity, I am become as sounding brass or tinkling cymbal. 
Charity from the King James Bible is now translated as "love," and "charity" comes from the Latin caritas of the Vulgate. Are we then to perceive that for Stephen to be a complete artist, he must recognize the need for caritas as well as the Scholasticclaritas in his aesthetic, if his work is to combine human significance and moral stature with perfection of form? As tephen parts from Bloom in "Ithaca," they both heard the ringing of bells, and for each, the sound brought intimations of mortality. Stephen and Bloom will die; they are mortal and yet, together with Molly, they seem to rise above the rest of their fellow Dubliners who jostle each other in an empty round of postures, drink, gossip, and fornication without connecting to one another in any meaningful way. Through love, or empathy, Stephen will, as an artist, connect back into life, to other people, and be able to portray the real lives of men and women, while seeing in the ordinary, the significant and transcendent. It is the power of love that will transform Stephen's abstract intellectuality and enable him to surmount his own mortality, to become the "priest of the eternal imagination (Portrait, p. 221).

\section{References}

O’Brien Darcy. 1968. The Conscience of James Joyce. Princeton: University Press.

Budgen Frank (Ed.) 1966. Letters of James Joyce. New York: Viking. Elmann Richard. 1966. Letters of James Joyce. Vols. II-III. London: Faber.

1977. The Consciousness of Joyce. London: Faber. 1972. Ulysses on the Liffey. London Faber.

Gifford Don with Seidman Robert. 1974. Notes for Joyce. New York: E. P. Dutton.

Gilber Stuart. James Joyce's “Ulysses.” (Revised Edition). London: Faber.

Hayman David. 1970. “The Empirical Molly,” Approaches to "Ulysses.” Thomas F. Staley and Bernard Benstock (Eds.) Pittsburgh: University Press.

Henke S. A. and Unkeless Elaine (Eds.) 1982. Women in Joyce. Urbana: University of Illinois Press.

Kenner Hugh. 1956. Dublin’s Joyce. Bloomington: Indiana University 
Press. 1980. Ulysses. London. Alleo and Unwin.

Joyce James. Ulysses: The Corrected Text. Hans Walter Gabler, with Wolford Steppe and Claus Melchior (Eds.) New York: Vintage Books.

Joyce James. 1966. A Portrait of the Artist as a Young Man. New York: the Viking Press.

Kenner Hugh. 1987. Ulysses, Revised Edition. Baltimore: The John Hopkins University Press.

Maddox Brenda. 1988. Nora: A Biography of Nora Joyce. New York: Ballantine Books

Schechner Mark. 1974. Joyce in Night Town. Berkeley: University of California Press.

Schwarz R. Daniel. 1987. Reading Joyce's “Ulysses.” New York: St. Martin's Press.

Scott K. Bonnie. 1984. Joyce and Feminism. Bloomington: Indiana University Press.

Tindall York William. 1950. James Joyce: His Way of Interpreting the Modern World. New York: Scribners.

Tindall York William. 1959. A Reader's Guide to James Joyce. New York: Farrar, Straus and Giroux. 